\title{
Kepemimpinan Ketua Yayasan Shine Al-Falah Pada Pondok Pesantren Perkampungan Minangkabau Dalam Pendidikan Kaum Dhuafa Kota Padang
}

\author{
Ahmad Sabri \\ UIN Imam Bonjol \\ ahmadsabri@uinib.ac.id \\ Heri Priyanto \\ UIN Imam Bonjol \\ priantoheri91@gmail.com
}

\begin{abstract}
In the view of Islam, the Dhuafa (orphans, destitute, neglected children) occupy the privileges of Allah SWT and His Apostles as in Surah Al-Maun Verses 1-3, for this, it is needed help from individuals and institutions to be able to maintain survival, and not displaced to become irresponsible people. This study illustrates how the Chairman of the Shine Al-Falah Foundation's leadership in fostering the Minangkabau village boarding school for the poor and the Shine Al-Falah Foundation's synergy with the government, donors, and the community. This research uses a qualitative method with a descriptive type. Primary data sources are the chairman, the supervisor of the Shine Al-Falah foundation, while the secondary data are the leader of the Islamic Boarding School, the laziswaf management, the orphanage management, the male / female boarding supervisor and the students. Data collection uses observation, interviews, and documentation. The results showed the leadership of the chairman of the Foundation Shine Al-Falah succeeded in fostering the Minangkabau village boarding school to be able to continue to exist in continuing education development by building participatory leadership to all stakeholders and trying to build synergy with relevant government agencies, the community and donors to run the program planned to meet the educational needs, infrastructure, basic food needs and so on that are suitable for children of poor people in Padang city, especially for children in the Minangkabau Village Islamic Boarding School.
\end{abstract}

Keywords : Leadership; The Dhuafa; Education.

Abstrak : Dalam pandangan Agama Islam kaum Dhuafa (anak yatim, fakir miskin, anak terlantar) menempati keistimewaan oleh Allah SWT dan Rasul-NYA sebagaimana dalam Q.S Al-Ma'un Ayat 1-3, untuk itu diperlukan bantuan dari pribadi dan lembaga- lembaga agar dapat menjaga keberlangsungan hidup, serta tidak terlantar hingga menjadi orang yang tidak bertanggung jawab. Penelitian ini menggambarkan tentang bagaimana Kepemimpinan Ketua Yayasan Shine Al-Falah dalam membina pondok pesantren perkampungan minangkabau bagi pendidikan kaum dhuafa dan Sinergitas Yayasan Shine Al-Falah dengan pemerintah, donatur dan masyarakat. Penelitian ini menggunakan metode kualitatif dengan jenis deskriptif. Sumber data primer yaitu ketua, pembina yayasan Shine Al-Falah, sedangkan data sekunder yaitu pimpinan ponpes, pengurus laziswaf, pengurus panti asuhan, pembina asrama putra/putri dan santiwan/ti. Pengumpulan data menggunakan observasi, wawancara dan dokumentasi. Hasil penelitian menunjukkan kepemimpinan ketua Yayasan Shine Al-Falah berhasil membina pondok pesantren perkampungan minangkabau untuk dapat tetap eksis dalam melanjutkan pembinaan pendidikan yaitu dengan cara membangun kepemimpinan yang partisipatif kepada seluruh stakeholder dan berupaya membangun sinergitas kepada instansi pemerintah terkait, masyarakat dan para donatur agar berjalannya program yang telah di rencanakan dalam memenuhi kebutuhan pendidikan, sarana prasarana, kebutuhan makanan pokok dan lain sebagainya yang layak bagi anak-anak kaum dhuafa di kota padang terkusus bagi anak-anak di Pondok Pesantren Perkampungan Minangkabau.

Kata Kunci : Kepemimpinan; Kaum Dhuafa; Pendidikan. 


\section{Pendahuluan}

Sebagai bagian dari salah satu negara berkembang di dunia. Indonesia dihadapkan selalu dengan berbagai krisis yang ada. Berdasarkan kondisi tersebut, Pembangiunan merupakan upaya yang dapat dilakukan Indonesia untuk berbenah mewujudkan perubahan yang nyata melalui pembentukan interaksi faktor-faktor yang terdapat dalam masyarakat seperti faktor ekonomi dan faktor manusia. Kualitas sumberdaya manusi menjadi masalah yang harus menjadi perhatian dan diprioritaskan dibandingkan kuantitas. Pendidikan merupakan cara yang dapat ditempuh untuk dapat mewujudkan manusia yang berkualitas (Wijaya et al., 2016).

Kemiskinan adalah masalah sosial yang banyak terdapat ditengah masyarakat negara berkembang. Kemiskinan selalu menjadi daya tarik banyak kalangan baik para akademisi maupun praktisi dalam mengkaji persoalan ditengah perekonomian yang lemah yang dihadapi bangsa Indonesia saat ini. Kemiskinan disebabkan bukan karena seseorang tidak rasional, atau memiliki budaya miskin atau kurangnya motivasi berprestasi yang dimiliki dan kewiraswataan atau lemahnya etos kerja, akan tetapi kondisilah yang menjadikan seseorang menjadi demikian karena dengan segala ketebatasan yang dimiliki atau sering disebut dengan istilah kaum dhuafa (Fakir, Miskin, anak yatim dan anak terlantar) (Ummah et al., 2018).

(Putra, 2019) menemukan bahwa sebagai negara berkembang yang sudah berumur 74 tahun yang memiliki 250 juta jiwa lebih penduduk, kemiskinan yang dihadapi oleh negara ini masih dikisaran angka 24\%, dengan standar hidup di bawah 1\$ US. Namun, akan melonjak jika standart hidup dibawah $2 \$$ digunakan, angka kemiskinan menjadi 35\%. Pembangunan ekonomi Indonesia dalam penanganan masalah pengentasan kemiskinan masih kurang efektif. Hal tersebut juga tergambar dalam laporan BPS pada bulan Maret 2015, jumlah penduduk miskin (penduduk dengan pengeluaran per kapita per bulan di bawah Garis Kemiskinan) di Indonesia mencapai 28,59 juta orang (11,22 persen), bertambah sebesar 0,86 juta orang dibandingkan dengan kondisi September 2014 yang sebesar 27,73 juta orang (10,96 persen). Persentase penduduk miskin di daerah perkotaan pada September 2014 sebesar 8,16 persen, naik menjadi 8,29 persen pada Maret 2015. Sementara persentase penduduk miskin di daerah perdesaan naik dari 13,76 persen pada September 2014 menjadi 14,21 persen pada Maret 2015. (BPS, 2018). Hal ini menunjukkan bahwa masih terdapat angka kemiskinan yang cukup tinggi pada daerah-daerah provinsi yang ada di Indonesia.

Dalam pandangan Islam kaum Dhuafa (anak yatim, fakir miskin) menempati keistimewaan dalam pandangan Allah SWT dan Rasul-NYA, hal tersebut agar dapat menjaga keberlangsungan hidupnya, tidak terlantar hingga 
menjadi orang yang tidak bertanggung jawab, sebagaimana firman Allah Swt dalam Q.S Al-Ma'un Ayat 1-3 yaitu:

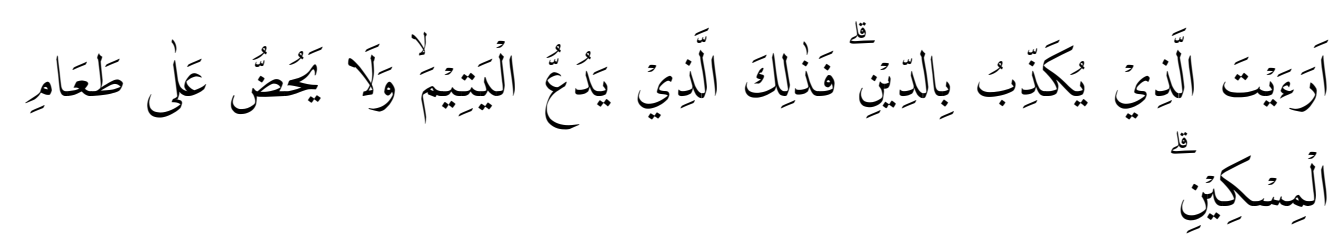

Artinya: 1. Taukah kamu orang yang mendustakan agama 2. Yaitu orang yang menghardik anak yatim 3. Dan tidak mau memberi makan orang miskin (Q.s. Al-Ma'un ayat 1-3)

Quraish Shihab dalam tafsirnya menyebutkan bahwa istilah yatim merujuk kepada seseorang manusia yang belum mencapai dewasa yang ayahnya telah meninggal dunia/wafat. Kematian ayah menyebabkan seseorang kehilangan pelindung, seolah-olah menjadi sendirian atau sebatang kara, sebab itu disebut dengan yatim. Orang miskin merupakan orang yang tidak memiliki apa-apa, tidak mempunyai rumah, memiliki sedikit pakaian dan makanan mereka hidup kelaparan. Ibnu katsir mentafsirkan miskin sebagai orang yang membutuhkan, yang tidak mampu dan menjaga dirinya (Iqbal, 2010).

Merekalah yang disebut dengan kaum Dhuafa (anak yatim, fakir miskin) yang kehilangan sosok yang mencari bekal hidupnya, sebelum paham dari apa itu pekerjaan, membimbing mereka sebelum mereka mengerti apa-apa merekalah kaum Dhuafa (anak yatim, fakir miskin dan orang terlantar lainnya) (Armylasari \& Wiludjeng, 2018).

Dalam Undang-Undang Dasar 1945 Pasal 34 ayat 1, menjelaskan bahwa Fakir miskin dan anak terlantar dipelihara oleh negara. Oelh karena itu kewajiban negara untuk dapat membekali memenuhi pendidikan dan berbagai soft skill sebagai bekal darianak-anak yang tidak mampu terutama kaum Dhuafa (Fakir Miskin, Anak yatim, anak terlantar serta anak-anak mualaf). Namun kenyataannya pemerintah belum dapat memberikan perhatian yang lebih sebagaimana menggantikan peran orang tua mereka serta belum optimal dalam memberikan penanganan tersebut (Ambat, 2013).

Pendidikan adalah jawaban dari mengatasi dan menjembatani masalah yang dihadapi oleh kaum Dhuafa dalam membentuk kepribadian yang kuat, tanggung jawab dan memiliki kepribadian yang baik serta mempunyai ilmu pengetahuan. Namun pada kenyataannya masih banyak anak yang mengalami hambatan sosial ekonomi sehingga mengakibatkan rendahnya pembimbinganan, pembinaan dan tuntunan kehidupan pada mereka terutama dalam hal pendidikan. Perlindungan dan perhatian terhadap anak-anak kaum Dhuafa (anak yatim, fakir miskin, dan anak terlantar lainnya) menjadi suatu keharusan dan 
tanggungjawab bagi umat islam dan tanggung jawab dari pemerintah (Tho'in, 2017).

Anak merupakan generasi penerus dan pewaris cita-cita perjuangan bangsa yang memiliki potensi sumber daya manusia (SDM) yang berkualitas. Anak miliki hak dan kebutuhan akan pendidikan serta memerlukan dukungan dari lingkungan keluarga dan sosial untuk kelangsungan hidupnya. Masalah krusial kondisi kemiskinan yang dihadapi dari anak yatim, fakir miskin adalah di antara mereka tidak mendapatkan pendidikan yang disebabkan oleh kurangnya biaya melanjutkan sekolah sehingga mereka harus berupaya memenuhi kebutuhannya sendiri dengan bekerja serabutan membantu orang mempekerjakannya, menjadi pengemis dan pengamen di jalanan, bahkan bertindak destruktif dilakukan demi kelangsungan hidupnya dengan tidak mengindahkan nilai- nilai agama, karena rendahnya pengetahuan dan pembinaan pendidikan agama. (Masruroh \& Farid, 2019).

Peran pendidikan sangat penting pada saat ini, karena tanpa pendidikan proses tranformasi aktualisasi pengetahuan modern tidak mudah untuk dapat diwujudkan. Pendidikan dalam kehidupan manusia menjadi wadah dalam membentuk generasi dimasa yang akan datang. Harapan dari proses pendidikan adalah menghasilkan manusia yang berkualitas, bertanggung jawab dan membawa perubahan positif dimasa depan. Pada hakikatnya pendidikan adalah menyiapkan dan mendampingi seseorang agar mendapatkan kemajuan dalam hidupnya. Pendidikan dapat membentuk karakter anak dengan mengetahui baik buruknya perbuatan mereka, hal tersebut juga bisa dipelajari dalam pendidikan Islam, karena melalui sistem pendidikan Islam membentuk manusia muslim sesuai dengan cita-cita pandangan Islam. Ajaran Islam tidak memisahkan antara iman dan amal sholeh, oleh karena itu pendidikan Islam adalah sekaligus pendidikan iman dan amal (Alam, 2017).

Dalam Undang-Undang No. 20 Tahun 2003 tentang Sisdiknas dijelaskan bahwa: "Pendidikan adalah usaha sadar dan tcrencana untuk mewujudkan suasana belajar dan proses pembelajaran agar peserta didik secara aktif mengembangkan potensi dirinya untuk memiliki kekuatan spiritual, keagamaan, pengendalian diri, kepribadian, kecerdasan, akhlak mulia serta keterampilan yang diperlukan dirinya, masyarakat, bangsa dan negara". Untuk dapat mewujudkan tujuan pendidikan tersebut, maka di perlukan seorang tokoh pemimpin/leader yang dapat mengayomi bawahan/anggotanya. Salah satu faktor yang menjadi penentu keberhasilan dalam organisasi adalah seorang pemimpin, sebab setiap manusia memiliki perbedaan baik pengalaman, pendidikan, kondisi, lingkungan, pribadi, dan lain sebagainya. Pemimpin dalam menjalankan kepemimpinannya harus memotivasi, mengarahkan, dan membi mbing semua komponen (Hakim, 2016). 
Kepemimpinan adalah suatu proses yang dapat memberikan pengaruh terhadap kegiatan-kegiatan kelompok dalam usaha menentukan tujuan yang ingin dicapainya, seorang pemimpin harus mempunyai banyak kecakapan seperti cakap dalam berkomunikasi, berkoordinasi, mempengaruhi, pembagian tugas sesuai dengan pekerjaan masing-masing. Kepemimpinan mempunyuai kekuatan dalam memberikan pengaruh melalui sikap keteladanan (qudwah), trust, dan memberikan inspirasi kepada seseorang/sekelompok orang untuk mencapai tujuan tertentu yang telah ditentukan bersama (Khamdani, 2014).

Kepemimpinan pendidikan islam memiliki pandangan dan prinsip yang kuat amanah, dan adil terhadap hak dan kewajiban anggota/karyawannya. Sarana yang dijadikan untuk menangkap setiap aspirasi anggota, masyarakat adalah dengan jalan musyawarah. Pencapaian tujuan pendidikan memerlukan etika tauhid dan penegakan amarma'ruf nahimunkar dengan memanusiakan manusia secara sungguh-sungguh. Kepemimpinan memiliki lima fungsi yaitu: (fungsi intruksi, konsultasi. partisipasi, delegasi dan pengendalian) (Fadhli, 2019).

Banyak penelitian terdahulu yang menggambarkan bagaimana kepemimpinan dalam lembaga pendidikan islam di pesantren (Arifin, 2018; Aziz \& Taja, 2016; Falah, 2019; Rahmat \& Karomah, 2019). Sebagai contoh sebuah penelitian tentang gaya kepemimpinan seorang kiyai dalam mengelola sebuah Pondok Pesantren Darul Ihsan di kabupaten garut. Hasil penelitian menunjukkan gaya kepemimpinan yang ditunjukkan oleh pemimpin pesantren adalah gaya kepemimpinan yang demokrasi. Sedangkan, dalam mengambil keputusan kiyai mengambil keputusan yang induced yaitu pengambilan keputusan yang didahului melalui analisis data berdasarkan fakta serta informasi dengan mempertimbangkan situasi dan kondisi. Selanjutnya mekanisme musyrawarah dalam menetapkan program-program yang dijalankan dalam pesantren.

Penelitian lain yang dilakukan (Fithriah, 2018) untuk melihat gaya kepemimpinan dari tiga pondok pesantren yang berbeda yaitu salafiyah, modern dan kombinasi, hasil penelitian menemukan terdapat ciri khas dari masingmasing gaya kepemimpinan yaitu gaya kepemimpinan yang kharismatik dan demokratis pada pondok pesantren Nurul Muhibbin, gaya kepemimpinan Laissez faire atau konsultasi delegasi pada pondok pesantren Rasyidiyah Khalidiyah, serta gaya kepemimpinan yang demokratis melalui musyawarah diterapkan oleh pimpinan pondok pesantren Al-Falah.

Yayasan Shine Al-Falah dipimpin oleh seorang ketua yayasan yang mengelola sebuah yayasan yang menaungi lembaga pendidikan baik formal maupun nonformal yaitu : 1). Pondok Pesantren Perkampungan Minangkabau (Madrasah Aliyah Swasta (MAS) Al-Falah, Madrasah Tsanawiyah (MTsS) AlFalah, Madrasah Ibtidaiyah Qur'an (MI-Q) Al-Falah. 2). Panti Asuhan Al-Falah: 3) Rumah Qur'an Al-Falah. Yayasan ini merupakan lembaga yang menjembatani 
pendidikan untuk kaum dhuafa yang bertekad untuk membantu dan memberdayakan pendidikan anak-anak kaum Dhuafa (Fakir Miskin, Anak yatim, anak terlantar) secara gratis dan tetap eksis sampai saat ini untuk pendidikan bagi kaum dhuafa.

Berdasarkan observasi lapangan, banyak permasalahan yang terjadi di Yayasan Shine Al-Falah dan Pondok Pesantren Perkampungan Minangkabau yaitu diantaranya: fasilitas prasarana yang kurang memadai, seperti bangunan sekolah asrama putra maupun putri, kebutuhan sehari-hari peserta didik dari segi makanan pokok, peralatan belajar, dan fasilitas lainnya. Meskipun dalam keterbatasan yayasan Shine Al-Falah dan Pondok Pesantren Perkampungan Minangkabau tetap mampu eksis dalam melanjutkan pembinaan pendidikan.

Sebuah kebaharuan yang ditemukan dalam kepemimpinan yang berbeda dari kepemimpinan yang lain yaitu Ketua Yayasan Shine Alfalah yang dapat memberikan perhatian dan dukungan sangat besar terhadap keberlanjutan pendidikan anak-anak kaum dhuafa pada pondok pesantren perkampungan minangkabau.

Berdasarkan permasalahan dan kajian literatur terdahulu, maka peneliti tertarik mengkaji: "Kepemimpinan Ketua Yayasan Shine Al-falah Pada Pondok Pesantren Perkampungan Minangkabau Dalam Pendidikan Bagi Kaum Dhuafa di Kota Padang". Fokus penelitian ini pada hal-hal sebagai berikut: (1) Kepemimpinan Ketua Yayasan Shine Al-falah dalam membina Pondok Pesantren Perkampungan Minangkabau bagi pendidikan kaum dhuafa. (2) Kepemimpinan Ketua Yayasan Shine Al-falah pada Pondok Pesantren Perkampungan Minangkabau dalam memenuhi kebutuhan pendidikan bagi kaum Dhuafa. (3) sinergi yayasan Shine Al-falah dan Pondok Pesantren Perkampungan Minangkabau dengan pemerintah, donatur dan masayarakat dalam pendidikan bagi kaum dhuafa.

\section{Metode Penelitian}

Penelitian ini adalah penelitian lapangan (field research) yang bersifat deskriptif dengan menggunakan pendekatan kualitatif. Penelitian ini dilakukan di Pondok Pesantren Perkampungan Minangkabau Kota Padang. Sumber data primer yaitu ketua, pembina yayasan Shine Al-Falah, sedangkan data sekunder yaitu pimpinan ponpes, pengurus laziswaf, pengurus panti asuhan, pembina asrama putra/putri dan santiwan/ti. Pengumpulan data menggunakan observasi, wawancara dan dokkumentasi. Pengolahan data menggunakan trianggulasi data.

\section{Hasil Dan Pembahasan}

Berdasarkan dari observasi dan pengumpulan data dilapangan ditemukan bahwa : 


\section{Kepemimpinan Ketua Yayasan Shine Al-Falah Dalam Membina Pondok Pesantren Perkampungan Minangkabau}

Dalam memimpin yayasan shine al-falah yang lakukan oleh ketua yayasan berdasarkan wawancara dan pengamatan menemukan bahwa membentuk hubungan partisipatif kepemimpinan di Yayasan Shine Al-Falah guna untuk mempererat ikatan tali persaudaraan yang dapat menjadi kekuatan dalam pengembangan organisasi/lembaga pendidikan yang terdapat di Yayasan Shine al-falah karena hubungan partisipatif tersebut menghasilkan motivasi serta serta tertanam prinsip dan spirit untuk memajukan lembaga bersama, keadaan ini sesuai dengan penelitian yang dilakukan oleh (Azis, 2018), Pimpinan Pondok Pesantren Nurulhuda Pakandangan dalam pengambilan keputusan sebagai seorang pimpinan pondok tertinggi mengikutsertakan setiap steakholder yang terkait. Para Staf, dan segenap unsur yayasan serta orang tua dan alumni adalah pihak-pihak yang selalu terlibat dalam perumusan kebijakan.

Penelitian lain yang dilakukan (Lestari, 2016) juga menunjukkan bahwa kepemimpinan partisipatif berpengaruh sangat tinggi terhadap komitmen organisasi serta kepemimpinan partisipatif berpengaruh terhadap efektifitas implementasi renstra pada Madrasah Aliyah di Kabupaten Sukabumi Jawa Barat

Dalam membentuk hubungan yang partisipatif komunikasi itu sangat penting dalam sebuah organisasi, tanpa adanya jalinan hubungan dan komunikasi yang baik dalam sebuah organisasi maka akan berdampak negatif dan terkendala dalam memajukan sebuah organisasi tersebut, hubungan komunikasi yang efektif tampak dari rasa saling, percaya, menghormati, terbukaserta bertanggung jawab (Sugiarti et al., 2019).

Selanjutnya selain hubungan partisipasi ketua yayasan al-falah juga menerapkan program kepemimpinan. Hasil pengamatan dan wawancara yang dilakukan di yayasan shine Al-falah penerapan kepemimpinan di lingkungan yayasan shine al-falah ini merupakan kepemimpinan yang tak ubahnya dengan kepemimpinan pada umumnya yang berupaya melakukan sebaik mungkin dan bekerja sama dengan anggota lainya agar tercapainya tujuan yang di inginkan secara bersama-sama.

Penerapan program kepemimpinan yang ada diyayasan shine al-falah diantaranya; 1) Membangun kepemimpinan yang memiliki karakter, nilai, etika, integritas, moral, dan motivasi yang kuat berdasarkan visi, misi dan tujuan organisasi lembaga; 2) Membangun kepemimpinan yang unggul, memahami berbagai tantangan di masa depan, cerdas dalam mengelola sumber daya manusia untuk keberhasilan organisasi, lembaga dan stakeholder. 
Pengembangan dan Pembinaan Pada Pondok Pesantren Perkampungan Minangkabau Oleh Yayasan Shine Al-falah. Pada awainya Yayasan Shine AlFalah didirikan pada tanggai 12 Desember 2012 berbadan hukum Akta Notaris Yuliami SH No. 38 Tgl 12 Desember 2012 dan Keputusan MENKUMHAM RI No. AHU- 473 AH.01.04. Pada tahun 2013 Yayasan Shine Al-falah juga mengembangkan/membina /mendirikan Pondok Pesantren yang bernama Pondok Pesantren Perkampungan Minangkabau pada Tahun Ajaran 2013/2014. Yayasan Shine Al-falah didirikan atas dasar kepedulian terhadap pendidikan UMMAT.

Dari hasil pengamatan dan wawancara bahwa yayasan Shine Al-Falah mengembangkan lembaga pendidikan Pondok Pesantren Perkampungan Minangkabau ini berfokus untuk membantu dan menjembatani anak-anak dhuafa (Fakir Miskin, Anak yatim, anak terlantar serta anak-anak mualaf) untuk mendapatkan pendidikan secara gratis.

Sebuah penelitian yang dilakukan di lakukan (Wekke et al., 2017) di Pesantren Emeyodere yang berada di daerah minoritas muslim Papua Keunikan dari keberadaan pondok pesantren ini yaitu dalam hal pemgintegrasian pondok pesantren, madrasan dan panti asuhan. Penyelenggaraan pendidikan islam dilakukan secara terpadu dan terintegrasi antara pendidikan umum dan pendidikan keislaman dan menjadikan panti asuhan dalam kesatuan yang integral sebagai lambing dan representasi kesolehan socsal.

2. Kepemimpinan Ketua Yayasan Shine Al-Falah pada Pondok Pesantren Perkampungan Minangkabau dalam Memenuhi Kebutuhan Pendidikan Bagi Kaum Dhuafa.

a) Kepemimpinan Ketua Yayasan Shine Al-falah dalam Mengambil Keputusan.

Dalam kepemimpinan yang dipimpin oleh seseorang pengambilan tindakan keputusan dalam sebuah organisasi harus dilakukan, oleh karenanya perlu kehati-hatian dan kecermatan serta kececerdasan dalam membuat suatu keputusan, jika sebuah keputusan yang diambil salah atau kurang tepat, maka akan memberikan dampak negative pada organisasi/ lembaga yang dipimpinnya (Usman et al., 2017).

Pada Yayasan Shine Al-falah keputusan yang berkaitan dengan kegiatan lembaga selalu mufakatkan secara bersama, dan pengambilan keputusan tersebut selalu melibatkan stakholder yang berperan penting di dalamnya. Berdasarkan hasil pengamatan dan wawancara bahwa kepemimpinan di yayasan Shine AlFalah dalam mengambil keputusan melalui musyawarah terlebih dahulu setelah adanya kata sepakat melalui musyawarah baru keputusan di putuskan oleh ketua Yayasan.

Pada suatu lembaga pendidikan sosok leadership/kepemimpinan merupakan elemen yang sangat penting, suatu lembaga yang perkembangannya 
sangat baik dipastikan dipimpin oleh seorang pemimpin yang ideal. Sebagai pemimpin tertinggi jabatan ketua memiliki pengaruh yang kuat dan sangat besar, karisma dan wibawa yang dimiliki sangatlah disegani dan dihormati oleh masyarakat yang berada disekitar lingkungannya. (Tarup et al., 2017). Dalam kegiatan kepengurusan yang ada di Yayasan Shine Alfalah tidak terlepas dari bagaimana proses kepemimpinan yang ada di dalamnya, seluruh pengurus memberikan kebebasan kepada anggota-anggotanya untuk memberikan ide-ide yang perlu dicarikan solusi.

Pola kepemimpinan yang diterapkan di Yayasan Al-falah adalah kepemimpinan yang demokratis, karena setiap Setiap persoalan yang muncul akan dicarikan solusi permasalahan yang ada secara bersama dengan unit organisasi yang membutuhkan bantuan, mengikutsertakan unit lain yang juga dapat memberikan masukan-masukan yang bersifat membangun dalam pengembangan pendidikan yang te;lah dijalankan oleh organisasi Yayasan Shine Al-falah. Berdasarkan pengamatan dan wawancara bahwa kepemimpinan di yayasan Shine Al-falah menggunakan kepemimpinan yang demokratis yang selalu mementingkan musyawarah, mengkoordinasi, komunikasi dengan anggota lainnya dalam mencapai tujuan.

Sebuah penelitian yang dilakukan oleh (Ansor, 2014) tentang Gaya kepemimpinan seorang Kiai pada Pondok Pesantren Tahfidz Daarul Qur'an Cipondoh Tangerang, menemukan bahwa sebagai pemimpin sebuah pondok telah memenuhi persyaratan sikap dan gaya yang karismatis demokratis, dan situasional kendali bebas. Hal tersebut tampak dari pentingnya musyawarah, dapat menerima kritik serta saran yang penting terutama dalam hal persamaan antara hak dan kewajiban pengurus yayasan. Karismatik terlihat dari ketokohan popularitas Kiai dimasyarakat. Kepemimpinan situasional tampak dari dukungan penuh dan pengarahan yang diberikan, serta kendali bebas dalam menjalankan tugas berada ditangan ustad dalam pelaksanaan tugas yang sesuai tujuan pesantren.

\section{b) Strategi Yayasan Dalam Memenuhi Kebutuhan Pendidikan Bagi Kaum Dhuafa}

Strategi/manajemen sangat penting sekali dalam kebutuhan kerja yang akan dilakukan agar mencapai hasil yang diinginkan. Manajemen suatu organisasi tidak menyangkut dari beberapa aspek yaitu perencanaan (planing), organisasi (organizing), pengarahan (actuating) dan pengawasan (controling).

Dalam strategi/manajemen untuk memenuhi kebutuhan pendidikan bagi kaum dhuafa di yayasan ini diantaranya yaitu bekerja sama dengan partai, merekrut donatur, melakukan wirausaha diantaranya temak itik, usaha fealon, kotak infak di masjid-masjid, rekaning tabungan dan juga memanfa lembaga 
LAZ ( lembaga Amil Zakat) dan juga proposal yayasan dalam mencarikan dana untuk kebutuhan pendidikan bagi kaum dhuafa. lembaga amil zakat (LAZ) dibawah naungan Yayasan Shine Al-falah ini merupakan salah satu usaha/strategi yang dilakukan oleh pihak yayasan untuk mencari,mengumpulkan dan mengelola keuangan untuk terpenuhinya kebutuhan pendidikan bagi kaum dhuafa disini diantaranya bentuknya, seperti Kotak infak dimasjid-masjid, proposal Baznas, Dinas Sosial dll.

Berdasarkan pengamatan dan wawancara bahwa dalam memenuhi kebutuhhan pendidikan bagi kaum dhuafa pihak yayasan memanfaatkan lembaga amil zakat untuk mencari, mengumpulkan dan mengelola kebutuhan, keuangan untuk untuk berlangsungnya pendidikan bagi kaum dhuafa.

\section{Sinergi Yayasan Shine Al-falah dan Pondok Pesantren Perkampungan Minangkabau Dengan Pemerintah, Donatur dan Masyarakat Setempat}

Sinergi merupakan kerjasama yang dilakukan oleh entitas yang berbeda secara menguntungkan untuk mencapai hasil akhir. Serderhananya, sinergi adalah perbuatan yang didalamnya saling mengisi dan melengkapi dari setiap perbedaan yang ada untuk mencapai tujuan akhir. Diperlukan sebuah konsistensi oleh masing-masing pihak yang dibangun melalui rasa saling percaya sebagai kerjasama kreatif (Suib, 2017).

Sinergi yang terjalin akan mampu membangun kerjasama-kerjasama kreatif sehingga terbentuk rasa menghormati perbedaan yang ada, menggalang kekuatan dan mengkompensasi dari kelemahan yang ada. Sinergi yang dilakukan oleh pihak yayasan Shine Al-falah dan Pondok Pesantren Perkampungan Minangkabau dengan pemerintah, donatur dan masyarakat setempat. Yayasan Shine Al-Falah dan Pondok Pesantren Perkampungan Minangkabau menjalin kerjasama dengan pemerintah guna menjalankan dari program-program pemerintah salah satunya adalah pemerintah memberikan bantuan baik materil maupun non materil dan pendampingan teknis pelaksanaan.

Bentuk sinergi yayasan Shine Al-Falah dan Pondok Pesantren Perkampungan Minangkabau dilakukan dengan pemerintah ini tentu yayasan ini telah terdaftar hukum Akta Notaris Yuliami SH No. 38 Tgl 12 Desember 2012 dan KEPUTUSAN MENKUMHAM RI No. AHU-473.AH.01.04, agar memudahkan apabila mendapatkan bantuan dari pemerintah. Diantara instansi pemerintah disini yaitu Dinas Sosial kota Padang, Dinas Pendidikan, Kementrian Agama Kota Padang serta Baznas kota Padang.

Berdasarkan pengamatan dan wawancara bahwa peran pemerintah sangat besar sekali terhadap yayasan dan pondok pesantren perkampungan minangkabau dalam proses pendidikan di yayasan Shine Al-falah. b. Sinergi dengan Donatur, Masyarakat Setempat dan Sekitarnya. Donatur biasanya datang 
dari masyarakat/orang yang mempunyai kelebihan harta yang ia berikan agar dapat meringankan beban seseorang kelompok. Dalam pengelolaan pendanaan Yayasan shine memanfaatkan lembaga amil zakat binaan Yayasan Shine Al falah yaitu Laziswaf (lembaga amil zakat infak shadaqoh wakaf).

Sebuah Penelitian yang dilakukan oleh (Fauzi, 2017) dalam hal permasalahan manajemen dan dan sumber dana pondok pesantren dapat diatasi dengan cara mengadobsi manajemen modern melalui studi banding ke lembaga pednidikan yang telah maju dalam pengelolaan lembaya, 3) melakukan pelatihan kewirausahaan dan membuat wirausaha yang dapat menjadi sumber kreativitas bagi santri dan melatih soft skill menghadapi perkembangan zaman yang semakin maju dan berdikari dalam keuangan, membuat network ekonomi, mengaktifkan perkoprasian, serta mengembangkan industri kecil (small bussines development) yang dapat meningkatkan pendapatan pondok pesantren.

Penelitian lain (Andi \& Muhtadi, 2018), menyebutkan bahwa pesantren yatim piatu dan dhuafa Adh Dhuhaa dan Al Fatih Sukoharjo santri yatim piatu dan keluarga miskin tidak hanya memperoleh ilmu-ilmu agama, pendidikan umu santri juga diberikan pembekalan terhadap ketrampilan hidup yaitu dengan beternak kambing dengan melakukan pelatihan pengembangan kemampuan usaha ternak dan resto tengkleng oleh para santri.

Bentuk pengelolaan dana bantuan dari donatur (lembaga Amil Zakat) yayasan Shine Al-falah yaitu :

1. Pola Pengumpulan Zakat

Dalam penghimpunan dana dari donatur, seperti zakat, infak, shadaqoh dan bantuan lainya kepada Yayasan shine Al-falah dengan cara yaitu :

a) Layanan langsung

Layanan ini donatur dapat memberikan langsung dana zakat, infak, shadaqoh dan wakaf ke kantor yayasan langsung terkusus lembaga binaan LAZ (Lembaga amil Zakat) Al-falah

b) Layanan antar jemput

Layanan ini merupakan layanan pengumpulan dana zakat, infak, shadaqoh dari donatur dalam bentuk kotak infak di Masjid/Mushalla, rumaV makan/Restoran, yang tersebar di kota Padang.

c) Proposal bantuan

Layanan ini dalam bentuk proposal bantuan yang diberikan kepada instansi pemerintah seperti Kementerian agama, Dinas sosial, para dermawan da pejabat

d) Layanan ini para muzakki dapat memberikan zakat melalui bank, bauk dengan eara tranfer ATM maupun SMS Banking. Tranfer tersebut dapat melalui rekening BRI dengan No Rekening: 547501027014539 a/n Laziswaf Al-Falah 
Berdasarkan pengamatan dan wawancara bahwa dalam memenuhi kebutuhan pendidikan dan kebutuhan pokok anak-anak dhuafa di Yayasan Shine al-falah yaitu dengan memanfaatkan kotak infak dimasjid/mushalla dan rekening Bank.

2. Pola Pendistribusian Dana Laziswaf

Untuk Pendidikan, setelah terkumpulnya dana dari donatur maka selanjutnya melakukan audit/penghitungan berapa pemasukan, setelah selesai perhitungan maka akan di alokasikan kepada Pondok Pesantren Perkampungan Minangkabau untuk pendidikan anak-anak dhuafa seperti alat tuli, pakaian dan lain sebagainya. Seperti yang diungkapkan Bapak adi Sahyogi selaku Pimpinan pondok pesantren Perkampungan Minangkabau. Untuk biaya pendidikan di pondok pesantren perkampungan minangkabau yaitu dana dari yayasan Shine Al-falah untuk biaya pendidikan seperti alat tulis, pakaian anak-anak dhuafa dan kebutuhan lainya.

Selanjutnya, untuk kebutuhan pokok Dana dan laziswaf selanjutnya juga diberikan kepada panti asuhan Yayasan Shine Al-falah untuk memenuhi kebutuhan pokok anak-anak dhuafa di Panti asuhan dan di asrama Putra/maupun Putri. Salah satu dana yang di dapatkan yaitu dari laziswaf, dana tersebut sangat membantu sekali anak-anak untuk memenuhi makanan pokok di Panti asuhan. Dana dari Laziswaf sangat besar sekali manfaatnya bagi anak-anak dhuafa untuk memenuhi kebutuhan pokok di asrama untuk membuat anak-anak dhuafa sehat,bergizi untuk proses pendidikan di Pondok Pesantren Perkampungan Minangkabau.

(TEMPO, 2014) menyebutkan, sebanyak 217 triliun rupiah potensi zakat penduduk muslim Indonesia belum semua yang dapat terserap dengan optimal. Oleh karena itu zakat jika dimanfaatkan dapat menjadi instrument people to people transfer sebagai solusi terbaik dalam mengatasi ketimpangan dan kesenjangan ekonomi (Nur Wahyuny, 2016).

Sebuah penelitian oleh (Ummah et al., 2018), implementasi dari alokasi ziswaf untuk menyediakan akses pendidikan bagi kaum dhuafa dilakukan dengan penyaluran zakat berbentuk beasiswa, kepada kaum dhuafa berupa pendanaan program maupun operasional sekolah. Penyaluran Infak, dimanfaatkan dalam hal mensupport pendanaan sekolah, pemberian gaji karyawan, pemeliharaan dari asset-aset lembaga sampai pengadaan fasilitas. Penyaluran Sedekah digunakan lebih luas seperti beasiswa berprestasi maupun pengadaan fasilitas yang dibutuhkan. Penyaluran Wakaf, berbentuk pengadaan dari lahan/banguna yang dapat mendukung operasional sekolah. 


\section{Kesimpulan}

Kepemimpinan Ketua Yayasan Shine Al-Falah pada Pondok Pesantren Perkampungan Minangkabau dalam pendidikan bagi kaum Duafa di kota Padang memiliki kepemimpinan yang partisipatif cukup baik pad setiap stakeholder yang ada. Dengan adanya jalinan komunikasi dan hubungan yang baik maka akan mampu mengerjakan tugas secara bersama-sama serta mempererat ikatan tali persaudaraan yang dapat menjadi kekuatan dalam pengembangan organisasi/lembaga pendidikan yang terdapat di Yayasan Shine al-falah karena hubungan partisipatif tersebut menghasilkan motivasi dan spirit untuk memajukan lembaga bersama. Dalam mengambil keputusan di Yayasan Shine Al-Falah ini selalu bersifat demokratis dengan azas musyawarah untuk mencapai mufakat dari segala aktivitas dan kegiatan yayasan. Setiap persoalan yang muncul akan dicarikan solusi permasalahan yang ada secara bersama dengan unit organisasi yang membutuhkan bantuan, mengikutsertakan unit lain yang juga dapat memberikan masukan-masukan yang bersifat membangun dalam pengembangan pendidikan yang telah dijalankan oleh organisasi Yayasan Shine Al-falah. Dalam memenuhi kebutuhan pendidikan bagi kaum duafa diantaranya yaitu bekerja sama dengan partai, merekrut donatur, melakukan wirausaha diantaranya ternak itik, usaha galon, kotak infak di masjid-masjid, rekaning tabungan dan juga memanfaatkan lembaga LAZ (lembaga Amil Zakat) dan juga proposal yayasan dalam mencarikan dana untuk kebutuhan pendidikan bagi kaum duafa. Sinergi Ketua Yayasan Shine Al-Falah dan pondok Pesantren Perkampungan Minangkabau dengan Pemerintah, Donatur dan Masyarakat Setempat. Sinergi dengan instansi pemerintah dilakukan untuk mendapat dukungan dari pemerintah seandainya jika bantuan agar yayasan dan pondok pesantren ini juga mendapatkan bantuan, selama ini bantuan diantaranya bantuan beras, dari dinas Sosial, dana Bos untuk Pondok Pesantren dari Kemenag Kota Padang dan juga bantuan Baznas Kota Padang.

\section{Daftar Pustaka}

Alam, L. (2017). Aktualisasi Pendidikan Islam Dalam Keluarga (Perspektif AlQur'an Surat Luqman). Muaddib: Studi Kependidikan Dan Keislaman, 6(2), 162. https://doi.org/10.24269/muaddib.v6n2.2016.162-1816

Ambat, T. K. (2013). Fungsi Negara Memelihara Anak- Anak Terlantar Menurut Undang- Undang Dasar 1945. Lex Administratum, 1(2).

Andi, S., \& Muhtadi. (2018). IbM Pengembangan Usaha Ternak Kambing di Pondok Pesantren Yatim Piatu dan Dhuafa di Kabupaten Sukoharjo. The 7th University Research Colloquium 2018, 8-12.

Ansor, A. S. (2014). Manajemen Pendidikan Islam Tentang Kepemimpinan Kiai Di Pondok Pesantren Tahfidz Daarul Qur'an Cipondoh Tangerang. Jurnal 
14 | TADBIR : Jurnal Studi Manajemen Pendidikan, Vol. 4, No. 1, Mei 2020

Pendidikan Islam, 3, 397-407.

Arifin, Z. (2018). Manajemen Konflik Pada Kepemimpinan Kolektif BPK-P2L Pondok Pesantren Lirboyo Kediri. ,. Jurnal Pemikiran Keislaman, 29(1), 177205.

Armylasari, E. T., \& Wiludjeng, F. A. (2018). Peran Komunitas Berbagi Nasi Dalam Membantu Pemerintah Untuk Mensejahterakan Kaum Dhuafa. Translitera: Jurnal Kajian Komunikasi Dan Studi Media, 5(2), 1-13. https://doi.org/10.35457/translitera.v5i2.359

Azis, A. (2018). Partisipasi Dalam Pengambilan Keputusan Pendidikan di Pondok Pesantren Nurul Huda Pakandangan SumenepJurnal Refl. Reflektika, 13(1), 105-118. https://doi.org/10.28944/reflektika.v13i1.99

Aziz, H., \& Taja, N. (2016). Kepemimpinan Kyai dalam Menjaga Tradisi Pesantren (Studi Deskriptif di Pondok Pesantren Khalafi Al-Mu'awanah Kabupaten Bandung Barat). Ta'dib: Jurnal Pendidikan Islam, 5(1), 9-18.

BPS. (2018). Profil Kemiskinan di Indonesia Maret 2018. Badan Pusat Statistik.

Fadhli, M. (2019). Internalisasi Nilai-Nilai Kepemimpinan Profetik Dalam Lembaga Pendidikan Islam. At-Ta'dib: Jurnal Ilmiah Prodi Pendidikan Agama Islam, 116-127.

Falah, S. (2019). Model regenerasi dan kaderisasi kepemimpinan pondok pesantren di Kabupaten Bogor. Ta'dibuna: Jurnal Pendidikan Islam, 8(1), 1 16.

Fauzi, A. (2017). Manajemen Dana dan Sumber Dana Pondok Pesantren. Tasyri', 24(01), 60-76.

Fithriah, N. (2018). Kepemimpinan Pendidikan Pesantren (Studi Kewibawaan Pada Pondok Pesantren Salafiyah, Modern, dan Kombinasi). Al Qalam: Jurnal Ilmiah Keagamaan Dan Kemasyarakatan, 12(1), 13-30.

Hakim, L. (2016). Pemerataan akses pendidikan bagi rakyat sesuai dengan amanat Undang-Undang Nomor 20 Tahun 2003 tentang Sistem Pendidikan Nasional. EduTech: Jurnal Ilmu Pendidikan Dan Ilmu Sosial, 2(1), 53-64.

Iqbal, M. (2010). Metode Penafsiran al-Qur'an M. Quraish Shihab. Tsaqafah, 6(2), 248. https://doi.org/10.21111/tsaqafah.v6i2.120

Khamdani, P. (2014). Kepemimpinan dan Pendidikan Islam. Jurnal Madaniyah, Edisi VII, 259-276.

Kusen, K., Hidayat, R., Fathurrochman, I., \& Hamengkubuwono, H. (2019). 
Strategi Kepala Sekolah Dan Implementasinya Dalam Peningkatan Kompetensi Guru. Idaarah: Jurnal Manajemen Pendidikan, 3(2), 175-193.

Lestari, A. (2016). Pengaruh Kepemimpinan Partisipatif Dan Komitmen Organisasi Terhadap Efektifitas Implementasi Rencana Stratejik Pada Madrasah Aliyah Di Kabupaten Sukabumi Jawa Barat. Jurnal Administrasi Pendidikan UPI, 23(1), 114-129. https://doi.org/10.24235/orasi.v6i2.1433.g1013

Masruroh, I., \& Farid, M. (2019). Pengaruh Pengelolaan Ekonomi Produktif dalam Mengentaskan Kemiskinan di Kota Lumajang Studi pada Badan Amil Zakat Nasional (BAZNAS) Kabupaten Lumajang. Iqtishoduna: Jurnal Ekonomi Islam, 8(1), 209-229.

Nur Wahyuny, I. (2016). Efisiensi organisasi pengelola zakat nasional dengan metode data envelopment analysis. Lariba, 2(1), 1-12. https://doi.org/10.20885/jielariba.vol2.iss1.art1

Putra, A. D. (2019). Analisis faktor-faktor yang mempengaruhi tingkat pengangguran dan tingkat kemiskinan di indonesia. Jurnal Ilmu Ekonomi Mulawarman (IIEM), 3(2).

Rahmat, A., \& Karomah, F. F. (2019). Perilaku Kepemimpinan Kontingensi Kiai dalam Memanajerial Pondok Pesantren Al-Ittihad Lembung Timur Lenteng Sumenep. Indonesian Journal of Islamic Education Studies (IJIES), 2(2), 133-142.

Sugiarti, Wibowo, N. M., \& Hartati, C. S. (2019). Pengaruh Gaya Kepemimpinan Partisipasi dan Motivasi Kerja Terhadap Kinerja Guru Pada SDN Gugus III Balikpapan Utara. MAP Jurnal Manajemen Dan Administrasi), 1(4).

Suib, M. S. (2017). Sinergitas Peran Pondok Pesantren Dalam Peningkatkan Indek Pembangunan Manusia (Ipm) Di Indonesia. Jurnal Islam Nusantara, 1(2), 171-191. https://doi.org/10.33852/jurnalin.v1i2.34

Tarup, M., Rusdiawan, \& Wilian, S. (2017). Pengaruh Gaya Kepemimpinan Tranformational Ketua Yayasan Pondok Pesantren dan Sistem Pengambilan Keputusan Terrhadap Kinerja Guru Madrasah Tsanawiyah se Kecamatan Praya Timur. JurnaL Ilmiah Profesi Pendidikan, 2(1), 1-12.

TEMPO. (2014). Tikungan Tajam Amil Zakat. TEMPO.

Tho'in, M. (2017). Pembiayaan Pendidikan Melalui Sektor Zakat Muhammad. In Intergovernmental Panel on Climate Change (Ed.), Al-Amwal (Jurnal Kajian Ekonomi dan Perbankan Syariah) (Vol. 9, Issue 2, pp. 162-175). Cambridge 
16 | TADBIR : Jurnal Studi Manajemen Pendidikan, Vol. 4, No. 1, Mei 2020

University Press. https://doi.org/10.24235/amwal.v9i2.1794.g1189

Ummah, K. A., Riyadi, A., \& Herianingrum, S. (2018). Pola Implementasi Alokasi Ziswaf Dalam Penyediaan Akses Pendidikan Bagi Kaum Dhuafa. JEBI Jurnal Ekonomi Dan Bisnis Islam), 3(2), 247. https://doi.org/10.15548/jebi.v3i2.183

Usman, M. A., Santoso, E., \& Hidayat, N. (2017). Sistem Pendukung Keputusan Pemilihan Anggota Pengurus Harian Pondok Pesantren Menggunakan Metode Profile Matching (Studi Kasus Pondok Pesantren Putra Sabilurrosyad). Jurnal Pengembangan Teknologi Informasi Dan Imu Komputer (JPTIIK) Universitas Brawijaya, 135(10), 1176-1184.

Wekke, I. S., Siddin, \& Kasop, I. (2017). At-Tajdid : Jurnal Ilmu Tarbiyah AtTajdid: Jurnal Ilmu Tarbiyah, Vol . 6 No . 1, Januari 2017 Ismail Suardi Wekke ; Siddin ; Ibrahim Kasop. At-Tajdid: (Jurnal Ilmu Tarbiyah), 6(1), 129.

Wijaya, E. Y., Sudjimat, D. A., \& Nyoto, A. (2016). Transformasi Pendidikan Abad 21 Sebagai Tuntutan. Prosiding Seminar Nasional Pendidikan Matematika 2016, 1, 263-278. 